\title{
Correction to: Einstein, von Frisch and the honeybee: a historical letter comes to light
}

\author{
Adrian G. Dyer ${ }^{1,2} \cdot$ Andrew D. Greentree ${ }^{3}$ Jair E. Garcia ${ }^{1}$ Elinya L. Dyer ${ }^{4} \cdot$ Scarlett R. Howard ${ }^{5}$. Friedrich G. Barth ${ }^{6}$ (D)
}

Published online: 21 June 2021

(c) The Author(s) 2021

\section{Correction to: Journal of Comparative Physiology A https://doi.org/10.1007/s00359-021-01490-6}

Authors would like to update few corrections to their publication

Corrections to the list of references updated

Minor text corrections updated

The original article has been corrected.

Open Access This article is licensed under a Creative Commons Attribution 4.0 International License, which permits use, sharing, adaptation, distribution and reproduction in any medium or format, as long as you give appropriate credit to the original author(s) and the source, provide a link to the Creative Commons licence, and indicate if changes were made. The images or other third party material in this article are included in the article's Creative Commons licence, unless indicated

The original article can be found online at https://doi.org/10.1007/ s00359-021-01490-6.

Friedrich G. Barth

friedrich.g.barth@univie.ac.at

1 School of Media and Communication, RMIT University, Melbourne, VIC 3001, Australia

2 Department of Physiology, Monash University, Clayton, VIC 3800, Australia

3 ARC Centre of Excellence for Nanoscale BioPhotonics, School of Science, RMIT University, Melbourne, VIC 3001, Australia

4 Department of Computer Science and Software Engineering, Swinburne University of Technology, Hawthorn, VIC 3122, Australia

5 Centre for Integrative Ecology, School of Life and Environmental Sciences, Deakin University, Burwood, VIC 3217, Australia

6 Department of Neurosciences and Developmental Biology, Faculty of Life Sciences, University of Vienna, Althanstr.14, 1090 Vienna, Austria otherwise in a credit line to the material. If material is not included in the article's Creative Commons licence and your intended use is not permitted by statutory regulation or exceeds the permitted use, you will need to obtain permission directly from the copyright holder. To view a copy of this licence, visit http://creativecommons.org/licenses/by/4.0/.

Publisher's Note Springer Nature remains neutral with regard to jurisdictional claims in published maps and institutional affiliations. 